\title{
Square Wave Voltammetric and Computational Study of Thyroxine-Thiourea Interaction
}

\author{
Marwa N. Abdul-Fattah* Saddalah T. Sulaiman Haitham A. AL-Wahab \\ Department of Chemistry/ Collage of Science /University of Mosul \\ E-mail:marwa_nizar@yahoo.com*
}

(Received 19/9/2018;Accepted 25/10/2018)

\begin{abstract}
The voltammetric behavior of Thyroxine $\left(\mathrm{T}_{4}\right)$ was studied using square wave voltammetry in phosphate buffer solution at $(\mathrm{pH} 7.0)$ as supporting electrolyte. Thyroxine gives two well-defined reduction peaks at $\mathrm{Ep}_{1}(-0.359)$ volt and $\mathrm{Ep}_{2}$ (-1.01) volt versus the reference electrode $(\mathrm{Ag} / \mathrm{AgCl} / \mathrm{Sat} . \mathrm{KCl})$. The calibration curve is linear within a two range of concentration, first is $\left(1.996 \times 10^{-7}-19.61 \times 10^{-7}\right) \mathrm{M}$ with the $\mathrm{R}^{2}$ equal to (0.999) and (0.9963) for $\mathrm{Ep}_{1}$ and $\mathrm{Ep}_{2}$ respectively, and second $\left(0.996 \times 10^{-6}-11.857 \times 10^{-6}\right) \mathrm{M}$ with the $\mathrm{R}^{2}$ equal to $(0.9819)$ and $(0.9848)$ for $\mathrm{Ep}_{1}$ and $\mathrm{Ep}_{2}$ respectively. The Gibb`s free energy $(\Delta \mathrm{G})$, enthalpy $(\Delta \mathrm{H})$ and entropy $(\Delta \mathrm{S})$ changes of temperature dependent on $(\mathrm{K})$ were calculated using Van`t Hoff equation for Thyroxine and Thiourea binding. The molecular docking between Thyroxine and Thioureahas been studied, and the results indicates thatthe interaction between $\mathrm{T}_{4}$ and $\mathrm{TU}$ was mainly hydrogen bonding and van der Waal's interaction.
\end{abstract}

Keywords : Thyroxine, Thiourea, Interaction, Molecular docking.

\section{دراسة فولتامتري الموجة المربعة وحاسوبية للتذاخل ما بين الثايروكسين والثايويوريا}

تمت درلسة الخواص الفولتلمترية للثايروكسين بلستخدلم نقنية فولتلمتري الموجة المربعة في محلول الفوسفلت الم ظظم

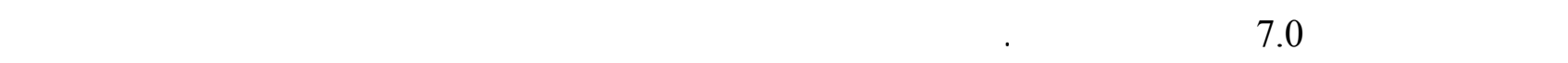

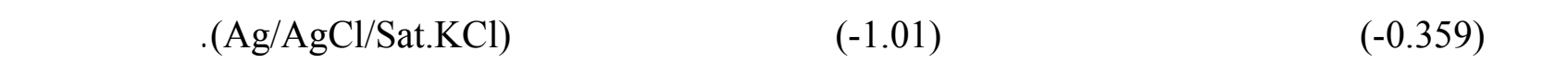

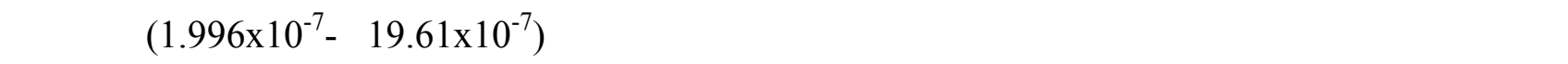

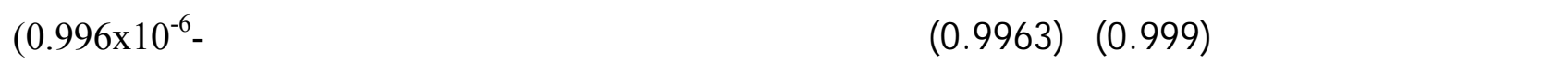

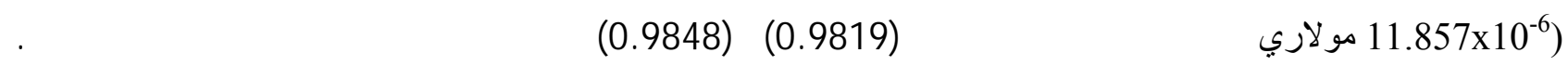

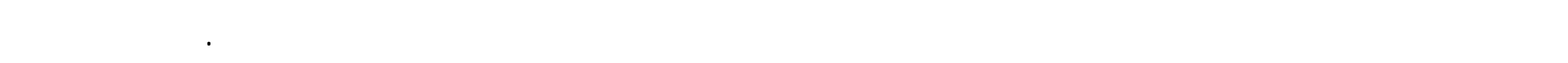

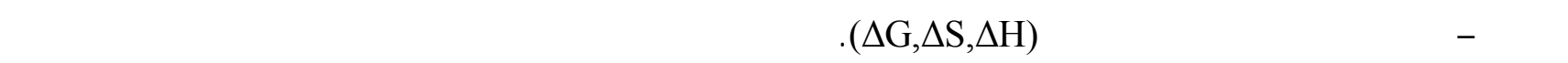
الارتبط ما بين الثايروكسين والثايويوريا هو ترابط باواصرر هيدروجينية وتدلخلات فلندرفالز. الكاملت الدالة : الثايروكسين، الثايرويوريا، التدلخلات، الاقتران الجزيئي. 


\section{INTRODUCTION}

L-Thyroxine $\left(\mathrm{L}-\mathrm{T}_{4}\right)(+)-3,5,3^{\prime}, 5^{\prime}$-tetraiodo-L-thyronine (Schem-1) is an important biological compound derived from tyrosine and produced by the thyroid gland (Voet et al., 2002). Also $\mathrm{T}_{4}$ is the main hormone secreted into the bloodstream by the thyroid gland. It is inactive and most of it is converted to an active form called triiodothyronine $\left(\mathrm{T}_{3}\right)$ by organs such as the liver and kidneys. Thyroid hormones play vital roles in regulating the body's metabolic rate, heart, digestive functions, muscle control, brain development and maintenance of bones, among many others effects not fully studied. The thyroid hormones $\mathrm{T}_{3}$ and $\mathrm{T}_{4}$ are unique in that iodine (as iodide) is an essential component of both (Murray et al., 2009).

The usual methods for the determination of $\mathrm{T}_{4}$ were UV- absorption(Gregorini, 2013), Radioimmunoassay(RIA) (Ping-Jun et al., 1983), HPLC (Sawabe et al., 2011), and Chemiluminescence (CL) (Gok and Ates, 2004).

However, these methods have some disadvantages such as expensive instrumentation, and time consuming and complicated operations. Electrochemical techniques have also been used for the detection of $\mathrm{T}_{4}$. Holak and Shostak (Holak and Shostak,1979) determined $\mathrm{T}_{4}$ by differential pulse polarography(DPP), with the use of ion-exchange resins to isolate the amino acids from the matrix, and the application of these methods in pharmaceuticals. Jacobsen and Fonahn (Jacobsen and Fonahn, 1980) carried out the most comprehensive study to date on the electrochemical behavior of $\mathrm{T}_{4}$ by DPP at a dropping mercury electrode (DME); they proposed a possible mechanism of reaction on the electrode surface. Both reports (Holak and Shostak, 1979) (Jacobsen and Fonahn, 1980) showed that the reduction of $\mathrm{T}_{4}$ involves the substitution of iodine by hydrogen. With the exchange of eight electrons and eight protons. Jacobsen and Fonahn found $\mathrm{T}_{4}$ to exhibit adsorptive properties at the surface of the DME on analyzing capillarity curves for solutions containing the amino acid. Also Hamdoon used DPP anddifferential pulse stripping voltammetry(DPS) methods for the determination of thyroxine(Hamdoon, 1989).

The glassy carbon electrode modified with Multi-Wall Carbon Nano Tubs(MWCNTs) was reported byK. Wu et al and applied the method to determine $\mathrm{T}_{4}$ in human serum (Wu et al., 2004).

In the present study, the electrochemical behavior of $\mathrm{T}_{4}$ anditsinteractionwith thiourea (TU) were studied as related simple compound to the antithyroiddrugs (Schem-2). In addition, the binding constant and thermodynamic parameters were also calculated.<smiles>C=C(C)C(C)Cc1cc(C)c(Cc2cc(C)c(C)c(C)c2)c(C)c1</smiles>

Schem-1 Structure of L-thyroxine<smiles>CCOC(=O)n1ccn(C)c1=S</smiles><smiles>Cn1cc[nH]c1=S</smiles><smiles>O=C1NC(=S)N[C@@H]2CCCCCC12</smiles>

Thiourea

Carbimazole

Methimazole

Propylthiouracil 


\section{EXPERIMENTAL}

\section{Reagents and Chemicals :}

Astock solution $\left(10^{-3} \mathrm{M}\right)$ of $\mathrm{L}_{-} \mathrm{T}_{4}$ was prepared by dissolving $\mathrm{T}_{4}$ (obtained from Alfa company, Germany) in $\left(0.1 \mathrm{M} \mathrm{NaOH}\right.$ in $70 \%$ ethanol solution); they were kept in darkness at $4{ }^{\circ} \mathrm{C}$,

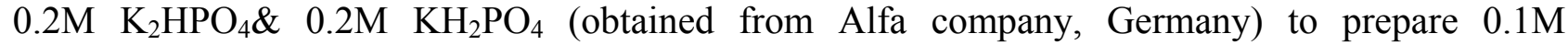
phosphate buffer solution (PBS) at $\mathrm{pH}$ 7.0. The buffer was adjusted to the required $\mathrm{pH}$ with the same solutions. Thiourea wasobtained from BDH laboratory reagent, andall solutions were prepared using deionized water and used without further purification.

\section{Apparatus :}

All voltammetric measurements were performed using 797- VA Computrace stand (Metrohm AG,CH-9101 Herisav, Switzerland). Reference electrode (RE) was Ag/AgCl/ Sat.KCl and Pt wire was used as auxiliary electrode (AE) and Hanging Mercury Drop Electrode (HMDE) was used as working electrode (WE). $\mathrm{pH}$ measurements were performed by using a digital $\mathrm{pH}$ meter (HAVANNA) calibrated with standard buffers, for temperature control a HAAKE G water bathwas used.

\section{Computational study:}

The Molecular Operating Environment MOE version (2009) software developed by (Chemical Computing Group, Montreal, Canada) was used for the graphical illustrations and molecular interaction study.

Molecular mechanics and quantum chemical calculations were performed to study the geometries and electronic structures. The 3D structures were drawn and used as the starting point for energy minimization. The energy minimizations were performed until the gradient was below (Minimum RMS Gradient $0.0001 \mathrm{Kcal} / \mathrm{mol} / \mathrm{A}^{\circ}$ ). Initial geometry optimization of molecule was carried out using molecular mechanics by the force field method (MMFF94x).

\section{Electrochemical behavior of $\mathbf{L}-\mathrm{T}_{4}$ :}

\section{RESULT AND DISCUSSION}

Preliminary measurements of $\mathrm{T}_{4}$ using SWV and the three-electrode system with HMDE as working electrode in PBS at $\mathrm{pH} 7.0$ as supporting electrolyte give two well-defined peaks at $(-0.359$ and -1.01) Vversus Ag/AgCl/Sat.KCl. As shown in Fig. (1) using optimum instrument conditions.

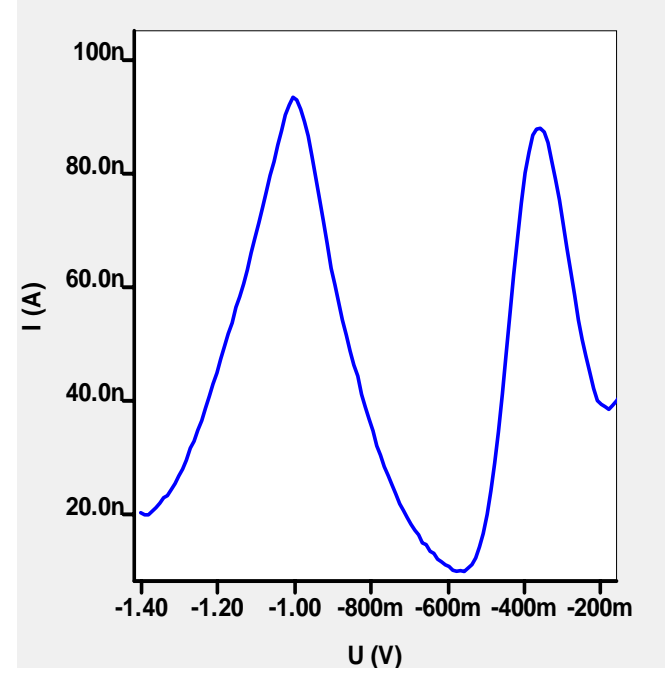

Fig.1: The S.W.Voltammogram of $\left(4.98 \times 10^{-6} \mathrm{M}\right) \mathrm{T}_{4}$ in PBS at $\mathrm{pH} 7.0$ 


\section{Optimum Condition for $\mathbf{T}_{\mathbf{4}}$ using SWV :}

A set of S.W. experiments were carried out using a solution containing $\left(4.98 \times 10^{-6}\right) \mathrm{M} \mathrm{T}_{4}$ in PBS pH 7.0.

The optimum conditions were obtained by changing the operating condition continuously and the best results obtained either givethe highest peak current or the best shape voltammogram, as showed in Fig. (1). The results obtained are shown in (Table 1) andthe obtained optimum condition was used in all thesubsequent experiments.

Table 1 : The optimum condition values of thyroxine by using SWV technique

\begin{tabular}{|c|c|}
\hline Conditions & Optimum Condition Values \\
\hline Deposition Potential (V) & -0.4 \\
\hline Deposition Time (Sec.) & 70 \\
\hline Equilibrium Time (Sec) & 5.0 \\
\hline Voltage Step (V) & 0.010 \\
\hline Amplitude (V) & 0.04 \\
\hline Frequency (Hz) & 50 \\
\hline Drop size (mm) & 7 \\
\hline pH & 7.0 \\
\hline
\end{tabular}

\section{Effect of L-thyroxine concentration :}

The calibration curve of $\mathrm{T}_{4}$ was constructed using SWV under the optimum conditions (Table 1) and potential between $\left(-1.4-{ }^{-} 0.1\right)$ V.The S.W.Voltammograms were recorded for the sequence additions of $\left(10^{-4}\right) \mathrm{M}$ and $\left(10^{-3}\right) \mathrm{M}$ respectively as stock solution of $\mathrm{T}_{4}$ in $(10 \mathrm{ml}) \mathrm{PBS}(\mathrm{pH}$ 7.0). Fig. (2) shows the result of these measurements, and the peak current plotted against the $\mathrm{T}_{4}$ concentration is shown in Fig. (3).

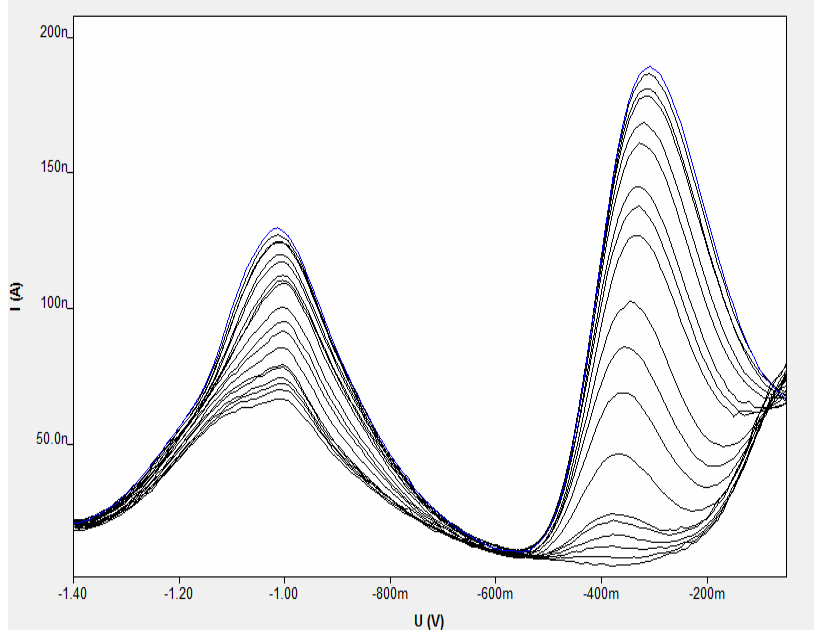

Fig. 2: Variation of Ip with $T_{4}$ concentration ( Calibration Curve )

A plot of peak current versusconcentrationsgives a two straight lines, the first at $\left(1.996 \times 10^{-7}\right.$ $\left.19.61 \times 10^{-7}\right) \mathrm{M}$ with the $\mathrm{R}^{2}$ equal to (0.999) and (0.9963) for $\mathrm{Ep}_{1}$ and $\mathrm{Ep}_{2}$ respectively, the second at $\left(0.996 \times 10^{-6}-11.857 \times 10^{-6}\right) \mathrm{M}$ range, with the $\mathrm{R}^{2}$ equal to (0.9819) and (0.9848) for $\mathrm{Ep}_{1}$ and $\mathrm{Ep}_{2}$ respectively. 

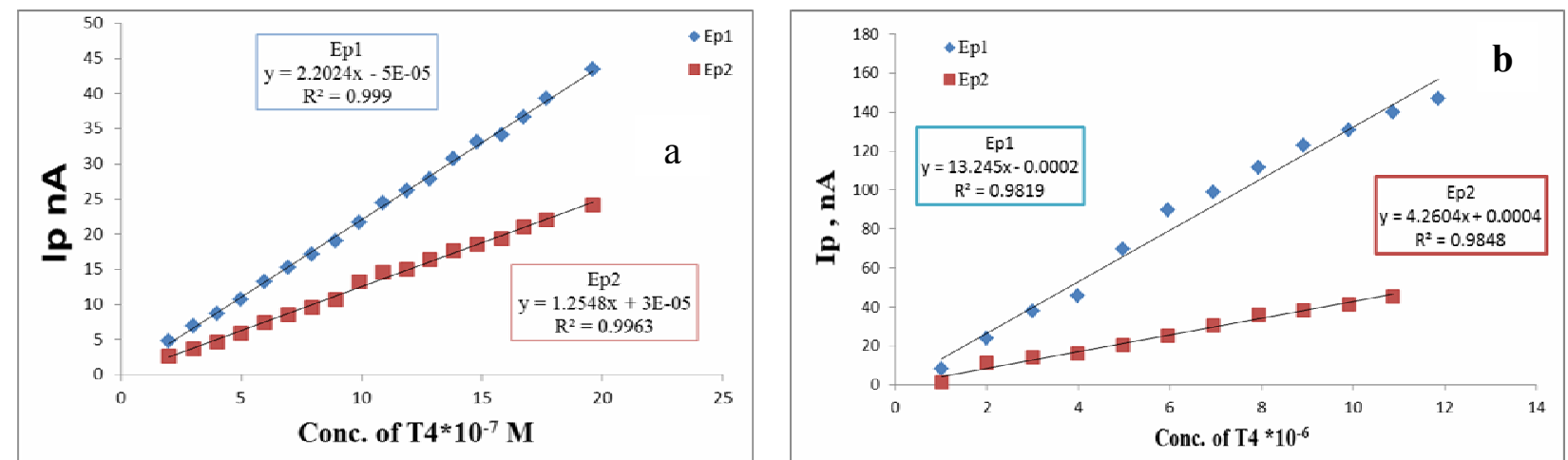

Fig. 3 : Plot of concentration of $\mathrm{L}-\mathrm{T}_{4} v S$. peak current.

(a) at $10^{-4} \mathrm{M}$ and (b) at $10^{-3} \mathrm{M}$ stock solution

\section{Voltammetric study of $\mathbf{T}_{4}$-TU Interaction:}

To study the interaction betweenThyroxine andThiourea, a successive amount of Thiourea $\left(1 \times 10^{-4}\right.$ Mas a stock solution) was added to voltammatric cell containing $\left(9.9 \times 10^{-6} \mathrm{M}\right)(\mathrm{L}$-Thyroxine) in phosphate buffer solution at ( $\mathrm{pH} 7.0)$ at different temperatures $(288,293,295,303){ }^{\circ}$ Kand the voltammogram was recorded for each addition. The peak current was measured at $\mathrm{Ep}_{1}=(-0.365 \mathrm{~V})$ because it is more sensitive than $\mathrm{Ep}_{2}$, which

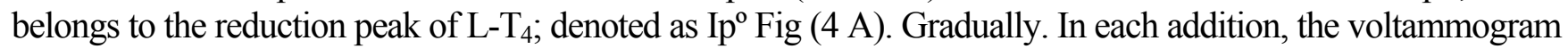
was recorded Fig (4 B) for second addition of Thiourea and the peak currents wave was measured at corresponding Ep and denoted as Ip.It is very clear from Fig. (4), the peak current Ip decreased gradually with the sequence addition of Thiourea until it reached constant value (saturation).

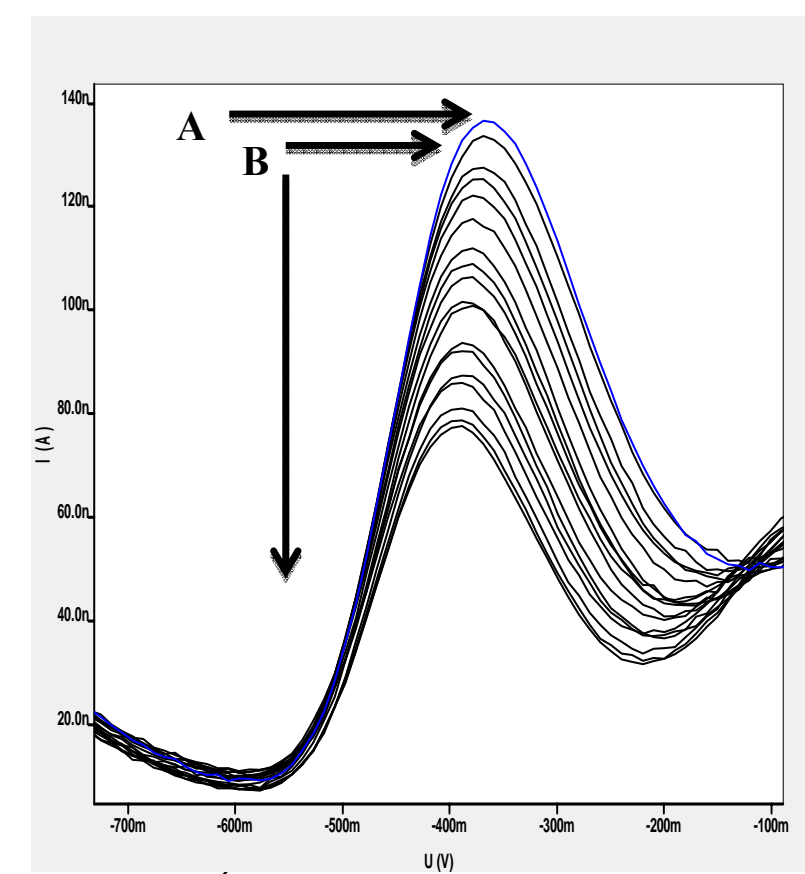

Fig.4 : SW Voltammogram $\left[9.9 \times 10^{-6}\right]$ molar (L-Thyroxine) in the A)absence of Thiourea B) with the successive additionsof Thiourea

Determination of Binding Constant (K) for (L-Thyroxine - Thiourea):-

The interaction of ( L-Thyroxine) withThiourea can be described using the following equation :-

$\mathrm{T} 4+\mathrm{TU} \longrightarrow \mathrm{T} 4-\mathrm{TU}$

An equation for voltammatric determination can be deduced according to (Jalali and Dorraji, 2012) the 
current diffusion equation was described as follows :-

$\ln \left(\operatorname{Ip} /\left(\operatorname{Ip}{ }^{\mathrm{o}}-\mathrm{Ip}\right)\right)=\ln (1 /[\mathrm{Conc} .(\mathrm{M})])-\ln (\mathrm{K})$

Where $\mathrm{K}$ is apparent binding constant, $\mathrm{Ip}^{\mathrm{o}}$ and $\mathrm{Ip}$, the peak current of the free $\left(\mathrm{T}_{4}\right)$ and the complex $\left(\mathrm{T}_{4-}\right.$ $\mathrm{TU})$, respectively. Then the plot of $\ln \left(1 /\left[\mathrm{Conc}\right.\right.$. Thiourea (M)]) versus $\ln \left(\mathrm{Ip} /\left(\mathrm{Ip} \mathrm{p}^{\mathrm{o}}-\mathrm{Ip}\right)\right)$ giveslinear relation with intercept of $-\ln (\mathrm{K})$ Equation (1).
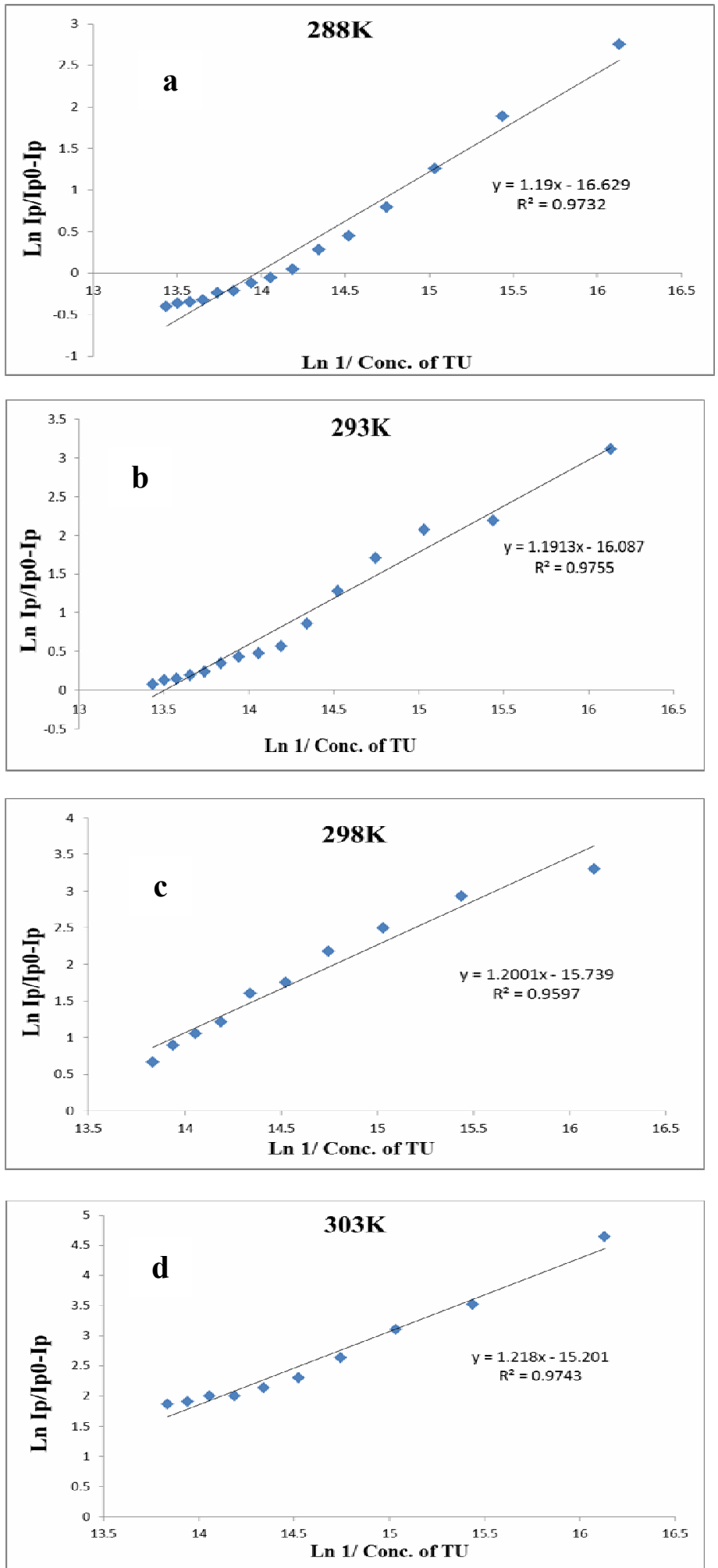

Fig. 5: (a-d) plot $\ln \left(1 /\left[\right.\right.$ Conc. of Thiourea (M)]) versus $\ln \left(I \mathrm{Ip} /\left(\mathrm{Ip} \mathrm{p}^{\mathbf{0}}-\mathrm{Ip}\right)\right)$ of Thyroxine and Thiourea interaction at $(\mathrm{a}=\mathbf{2 8 8}, \mathrm{b}=\mathbf{2 9 3}, \mathrm{c}=\mathbf{2 9 5}, \mathrm{d}=\mathbf{3 0 3}){ }^{\circ} \mathrm{K}$ 
Table 2: The binding constant at different temperature $(288,293,298,303)^{\circ} \mathrm{K}$

\begin{tabular}{|c|c|c|c|c|}
\hline Temp. $^{\mathbf{}} \mathbf{K}$ & $\mathbf{2 8 8}$ & $\mathbf{2 9 3}$ & $\mathbf{2 9 8}$ & $\mathbf{3 0 3}$ \\
\hline $\ln \mathbf{K}\left(\mathbf{E p}_{\mathbf{1}}\right)$ & 16.629 & 16.087 & 15.739 & 15.201 \\
\hline K x10 $^{\mathbf{6}}$ molar $^{-1}$ & 16.67 & 9.69 & 6.84 & 3.40 \\
\hline
\end{tabular}

The result shows that the value of $\mathrm{K}$ was decreased with increasing temperature.

\section{Calculation of Thermodynamic Parameters :-}

The plotting of $\ln \mathrm{K}$ against 1/T using Van ${ }^{\mathrm{t}}$ Hoff equation (Equation 2) gives a linear relationship Fig. (6). The enthalpy change $(\Delta \mathrm{H})$ was obtained from the slope, $\Delta \mathrm{S}$ from intercept and Gibb`s free energy $(\Delta \mathrm{G})$ was calculated from (Equation 3):

$\ln \mathrm{K}=-\Delta \mathrm{H} / \mathrm{RT}+\Delta \mathrm{S} / \mathrm{R}$

$\Delta \mathrm{G}=-\mathrm{RT} \ln \mathrm{K}$

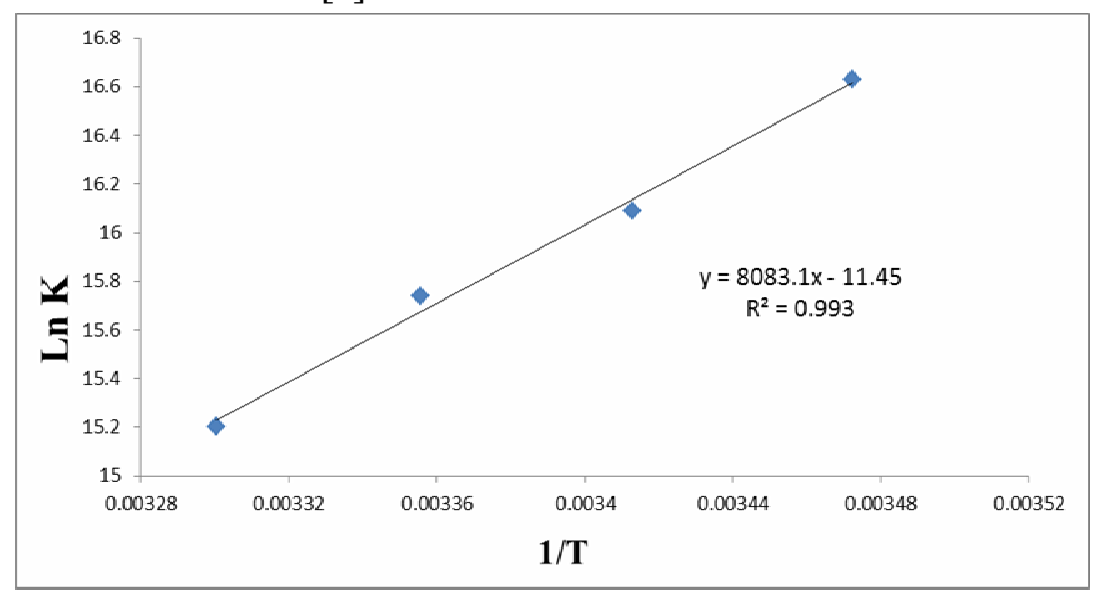

Fig. 6: The relation between $\ln K$ and $1 / T K^{-1}$ for interaction between $L-T h y r o x i n e$ and Thiourea

Table 3: The thermodynamic parameters at different temperatures $(288,293,298,303)^{\circ} \mathrm{K}$

\begin{tabular}{|c|c|c|c|c|c|c|}
\hline $\begin{array}{c}\text { Temp } \\
{ }^{\circ} \mathbf{K} \\
\end{array}$ & $1 / T$ & $\ln K$ & $\begin{array}{l}\mathbf{K} \times 10^{6}, \\
\text { molar }^{-1}\end{array}$ & $\Delta \mathbf{H}(\mathrm{KJ} / \mathrm{mole})$ & $\Delta \mathrm{G}(\mathrm{KJ} / \mathrm{mole})$ & $\Delta \mathrm{S}(\mathrm{J} / \mathrm{mole} . \mathrm{K})$ \\
\hline 288 & 0.003472 & 16.629 & 16.67 & \multirow{4}{*}{-67.202} & -39.817 & \multirow{4}{*}{-95.1953} \\
\hline 293 & 0.003413 & 16.087 & 9.69 & & -39.187 & \\
\hline 298 & 0.003356 & 15.739 & 6.84 & & -38.994 & \\
\hline 303 & 0.003300 & 15.201 & 3.40 & & -38.293 & \\
\hline
\end{tabular}

From (Table 3), it can be seen that the negativevalue of $\Delta \mathrm{G}$ reveals that the interaction process is spontaneous, the negativevalue of $\Delta \mathrm{H}$ indicates that the interaction is exothermic andthe negativevalue of $\Delta \mathrm{S}$ indicates that the interaction is order.

From thermodynamics parameters $(\Delta \mathrm{H}<0, \Delta \mathrm{S}<0)$, it is clear that the van der Waal's and hydrogen bonding is the main force in the interaction (Zhao, 2010).

Molecular Docking:

To predict the structure of molecular complex between two or more molecules (Ferreira et al., 2015), the molecular docking technique was performed as the best orientation and conformation of complex, as shown in Fig. (7). 


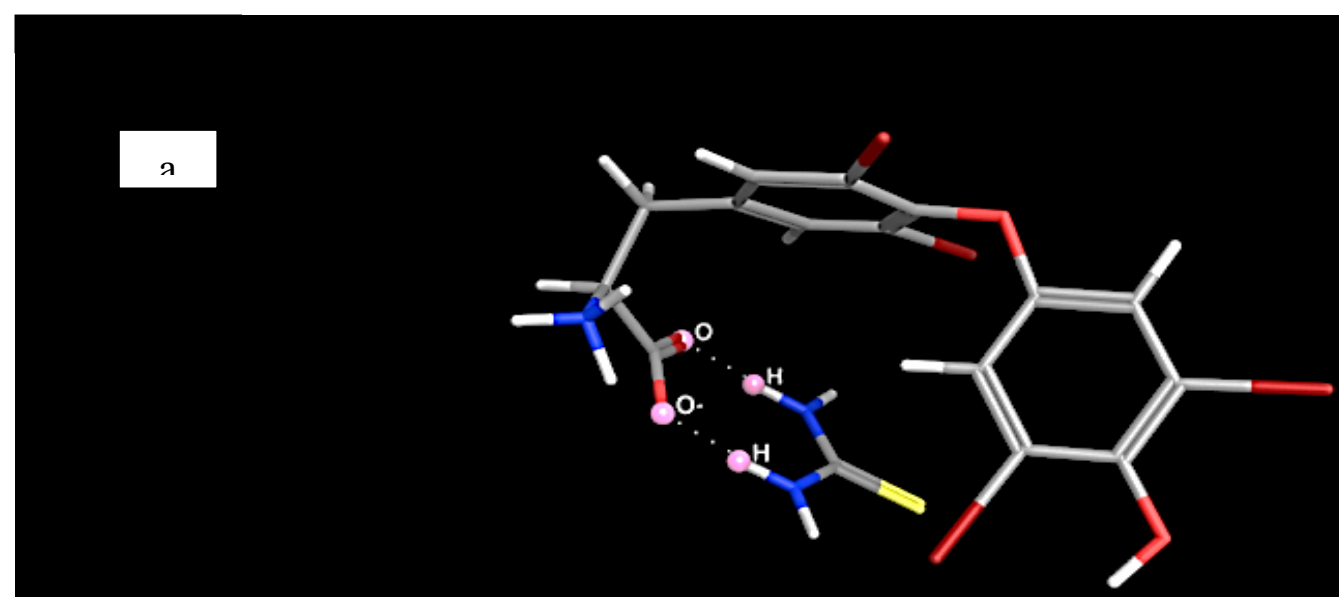

$\mathrm{b}$

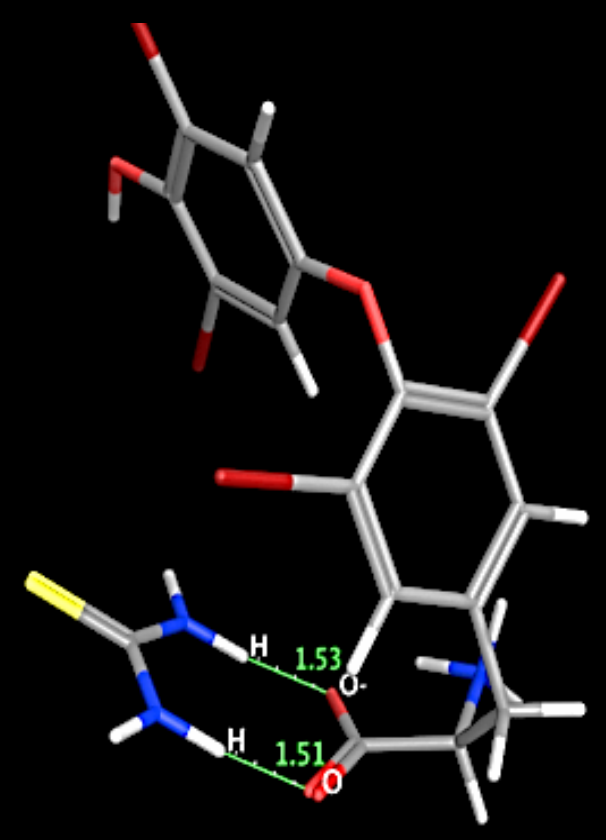

c

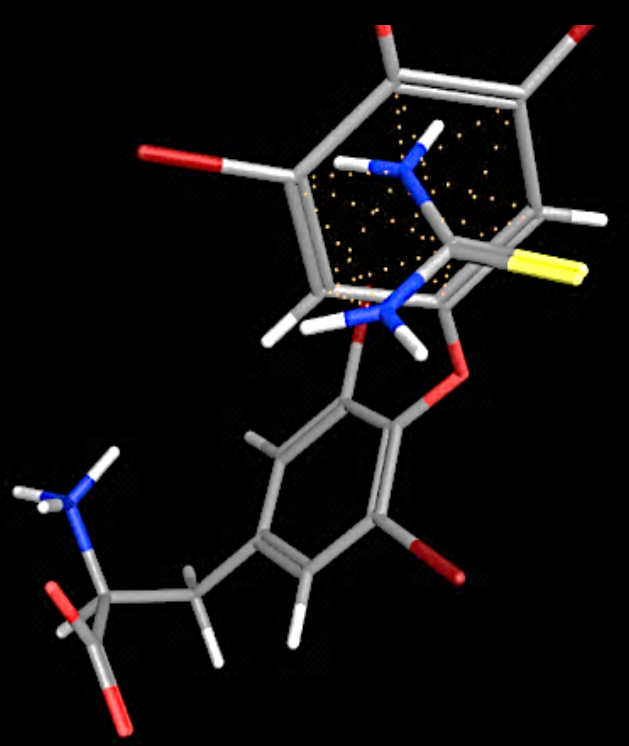

Fig. 7: Molecular Docking between Thyroxine and Thiourea 

forces.

Fig. (7a, 7b, 7c) shows that Thyroxine interacts with Thiourea by H-bonding and electrostatic

It can be seenfrom Fig. (7a, 7b) that the oxygen of carboxylic group of $\mathrm{T}_{4}$ was very closed with hydrogen of TU with distance 1.51 and $1.53^{\circ} \mathrm{A}$ as hydrogen bonding between them (as shown in Fig.(7a) and $7 \mathrm{~b}$ with white dashed line) and which wasaccepted with thermodynamic result about $\operatorname{Ep}_{1}(\Delta H<0$ and $\Delta S<0)$.

On the other hand, the phenolic ring ( $\pi$ electrone) of thyroxine, also interacted with nitrogen's of TU ring, makes a cation-pi interaction with the phenolic ring between the Nitrogen and the ring $\boldsymbol{\pi}$ electrons (as shown in Fig.(7c) with a yellow dashed line) suggest electrostatic forces. The result of molecular docking between T4 and TU shown in (Table 4).

Table 4: Molecular Docking result between $T_{4}$ and TU

\begin{tabular}{|c|c|c|}
\hline $\mathbf{E}_{\min }$ Of ligand(TU),Kcal/mol & $\mathbf{E}_{\mathbf{m i n}} \mathbf{T} 4, \mathbf{K c a l} / \mathbf{m o l e}$ & $\mathbf{T} 4-\mathrm{Lig}$ aft. Docking,Kcal/mole \\
\hline-29.4707 & 89.1110 & 14.3433 \\
\hline
\end{tabular}

\section{CONCULSION}

In this paper, the interaction of thyroxine hormone with thiourea has been studied by electrochemical method. The experimental results indicates that thiourea can interact with thyroxine through hydrogen bond and van der Waals force. The binding constant (K) between thyroxine and thiourea was determined to be $\left(16.67 \times 10^{6}-3.40 \times 10^{6}\right)$ at temperature range $(288-303)^{\circ} \mathrm{K}$, thermodynamic parameters also were calculated. The molecular docking also has been studied between thyroxine and thiourea.

\section{REFERENCE}

Ferreira, L.G.; dos Santos, R.N.; Oliva, G.; Andricopulo, A.D. (2015). Molecular Docking and Structure-Based Drug Design Strategies. Molecules, 20,13384-13421.

Gregorini, A.; Ruiz, M.E.; Volonte, M.G. (2013). A derivative UV spectrophotometry method for the determination of Levothyroxine sodium in tablets. J. Anal. Chem., 68, 6, 510-515.

Gok, E.; Ates, S. (2004). Determination of thyroxine hormone by luminol Chemiluminescence, Anal. Chim. Acta. 505,125.

Hamdoon, H.S. (1989). Differential-Pulse Voltammetric Measurement of Some Dehydrogenase Enzymes and Thyroid Hormons Clinical Applications. Ph.D., Thesis. University of Mosul.

Holak, W.; Shostak, D. (1979). Differential pulse polarographic analysis of thyroid hormone: determination of iodine, thyroxine and liothyronine. J. Pharm. Sci., 68(3), 338-42.

Jacobsen, E.; Fonahn, W. (1980). Determination of L-thyroxine sodium and triiodothyronine sodium in tablets by differential pulse polarography. Anal. Chim. Acta., 119, 33-38.

Murray, R.K.; Bender, D.A.; Botham, K.M.; Kennelly, P.J.; Rodwell, V.W.; Weil, P.A.(2009). "Harper`s Illustrated Biochemistry ". $28^{\text {th }}$ ed., McGraw-Hill, China, 874 p.

Ping-Jun, L. (1983). Solid phase radio immunoassay for thyroxine (T4). J. First Military Medical Un.

Sawabe, Y.; Tagami, T.; Yamasaki, K.; Taguchi, S. (2011). Determination of liothyronine and levothyroxine in dietary supplement by HPLC using a pre-column derivative. J. Health Sci., 57(1), 47-52.

Voet, D.; Voet, J.G.; Pratt, C.W.(2002). "Fundamentals of Biochemistry". John Wiley \& Sons. Inc., USA. pp. 90-91.

Wu, K.; Ji, X.; Fei, J.; Huet, S.(2004). The fabrication of carbon nanotube film on a glassy carbon electrode and its application to determining thyroxine. Nanotechnology, 15, 287-291.

Zhao, X.; Liu, R.; Chi, Z.; Teng, Y.; Qin, P. (2010). New insights into the behavior of bovine serum albumin adsorbed onto carbon nanotubes: comprehensive spectroscopic studies. J. Phys. Chem., 114, 5625-5631. 